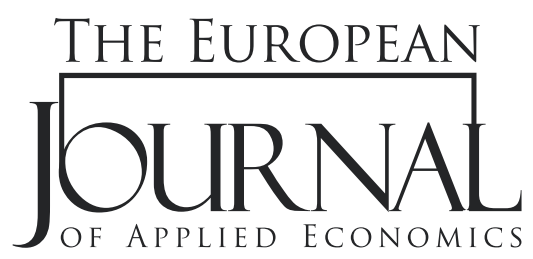

EJAE 2020, 17(1): $104-112$

ISSN 2406-2588

UDK: 336.652:331.56(4-191.2+4-11)

364.652:34

DOI: $10.5937 /$ EJAE17-23673

Original paper/Originalni naučni rad

\title{
DOES UNEMPLOYMENT LEAD TO CRIMINAL ACTIVITIES? AN EMPIRICAL ANALYSIS OF CEE ECONOMIES
}

\author{
Nemanja Lojanica*, Saša Obradović \\ Department of Macroeconomics, Faculty of Economics, \\ University of Kragujevac, \\ Serbia
}

\begin{abstract}
:
This paper attempts to shed light on the linkages between criminal behavior and unemployment, with special reference to Central and East European countries (CEE). The adequacy of this paper relies on the premise that an econometric modeling of the relation between these variables is very important for the explanation of economic and social growth. Our result is in line with the premise that crime goes up when unemployment rises. These findings suggest that, to combat crime, all strategies oriented to mitigate unemployment should be investigated. Furthermore, in order to successfully mitigate crime, governmental authorities in the CEE economies need to achieve macroeconomic stability.
\end{abstract}

\section{Article info:}

Received: October 19, 2019

Correction: December 19, 2019

Accepted: December 19, 2019

\section{Keywords:}

unemployment rate,

crime,

panel data econometrics,

Eastern and Central Europe.

\section{INTRODUCTION}

Criminal activities are a source of instability and insecurity in each national economy. This phenomenon, which is as old as a society itself and has global proportions, causes monetary costs and psychological consequences. Each country has a classification of illegal activities that are prohibited and sanctioned. Manners, definitions, and consequent sanctions of illegal activities differ among the countries. Availability of the data on crime represents a huge problem. The theory of economics treats crime market as an alternative to the labor market, and each individual's choice between these markets depends on personal cost-benefit analysis.

It is extremely significant for economic policy makers to determine the links between macroeconomic indicators and crime. Since unemployment is a key macroeconomic indicator and directly related to 
the labor market, it is essential to determine the relations between unemployment and the crime rate in order to deepen the understanding of the economic determinants of criminal activities. Taking into consideration the importance of this issue, this study aims to examine the impact of unemployment on crime rates in the selected CEE countries. The social welfare system in these countries was disassembled in the shift toward democracy (Pridemore et al., 2007). The choice of these countries relies on the fact that the transition process in most of them resulted in conflicts, turmoil, and an increase in crime rate. However, some issues, such as a higher crime rate, have still remained. The CEE countries experienced domestic and transnational crime. (Gruszczyńska, 2004). In order to examine the relevant aspects of the relations between unemployment and crime, panel data analysis was used as an appropriate approach in this study. Within this framework, an appropriate test of co-integration was selected in order to examine potential relations. The contribution of this paper is twofold. First, there are only a few studies which examine the crime problem on the sample of CEE countries. Second, there is no study which tested empirical regularity on the long-term relationship between crime and unemployment on the sample of CEE countries.

The paper is organized in the following way: it begins with a review of studies on the topic of the relation between unemployment and crime rates. This segment of the paper emphasizes controversies and differences in theoretical and empirical approaches to this problem. The third part begins with the presentation of panel tests of co-integration; the relations between the two variables are determined based on the results of the appropriate test of elasticity. The fourth part of the study reveals the main results, while the conclusion is dedicated to discussions concerning the obtained results.

\section{LITERATURE REVIEW}

The issue concerning the relations between macroeconomic indicators and crime rate has been a question of numerous debates. Pioneer initiatives in this field were undertaken by Becker (1968) and Ehrlich (1973). They opened the question of socioeconomic indicators that have an influence on crime rate, focusing primarily on poverty, social exclusion, incomes, income inequality, educational level, and unemployment. The relation between crime and economic performance from any angle cannot be overemphasized (Estrada and Ndoma, 2016). The previous studies in this field have most often tried to determine the relations between unemployment and crime rate. The main reason for the growing interest in this topic is that unemployment has profound effects on all spheres of society. Lee (2016) pointed out that the relation between unemployment and crime is equivocal. The nature of this relation is quite complex (Rosenfeld and Messner, 2013).

Pridemore (2005) employed socioeconomic data to examine the effects of social structure characteristics on the homicide rate in the Russian regions. Results revealed that poverty was positively associated with regional crime rates. Similarly, Kim and Pridemore (2005) suggested that high crime rate is associated with negative socioeconomic changes. By exploring crime trends across European countries, McCall and Brauer (2014) have shown that, in the short-run, positive changes in welfare spending are related with reductions in crime.

Macroeconomic models that examine criminal activities forecast that an increase in unemployment rates reduces opportunity costs of crime, while simultaneously increasing criminal activities. However, some empirical studies did not confirm this hypothesis. Namely, Mustard (2010) emphasizes that, after five decades of research dedicated to the links between labor market and crime, the primary problem is the gap that exists between theoretical and empirical results. 
The assumption that improvements in the labor market reduce crime seems economically justifiable, but empirical studies did not prove this in some cases. The differences in the results vary from a low impact of unemployment on crime rate, through statistical insignificance of the obtained results, to higher influence of some other macroeconomic indicators. For example, Gould et al. (2002) emphasize that income and unemployment are associated with crime rate, but that the income rate has a stronger influence still.

According to a study conducted for all Italian provinces, there is a positive causality between the unemployment rate and crime rate (Speziale, 2014). This complies with the results showing that there is a positive link between economic indicators, including unemployment rates, inflation rates, and inequality, as well as crime rates (Cheong and $\mathrm{Wu}, 2015$ ). This is not a coincidence, because the unemployment rate has a major role in explaining crime rate, according to some authors (Justus and Kassouf 2013).The majority of recently conducted empirical studies with panel samples have confirmed the hypothesis about the statistical significance of the correlations between labor market and crime (Papps and Winkelmann 2000; Cerro and Meloni, 2000; Edmark, 2003; Baharom and Habibullah, 2008; Almen and Nordin, 2011). The selected studies have had different econometric approaches. Furthermore, some studies have observed crime in aggregate and disaggregate manners.

Unemployment duration is usually mentioned as one of the main reasons for involvement in criminal activities (Bindler, 2014). The author tried to examine the relations between the conditions on the labor market and crime rate in the context of long-term unemployment in the USA. Using the quasi-experimental analysis of variations in unemployment and duration of unemployment benefits, the relations between higher crime rates and higher unemployment rates were confirmed. Longer-time periods of unemployment lead to the devaluation of human capital, and increases inclination towards criminal activities. Of all the studies conducted in this field, it is important to mention the following: Mocan and Unel (2011), Long and Polito (2014) and Bell et al. (2014). Mocan and Unel (2011) used the panel sample to determine variations in incomes of unqualified workers in the USA and their influence on their involvement in criminal activities. Long and Polito (2014) investigated individual motivations for finding a job in the presence of random criminal opportunities. These opportunities reduce moral hazard, since individuals sometimes commit a crime before they start searching for a job.

According to Bell et al. (2014), recession leads to short-term job loss, which results in income reduction. There is growing evidence that workers who join labor markets during economic crises face the inability to find a job fast and easily, which eventually has a negative impact on their earnings and further career development. Young people who finish school during a recession are more likely to engage in criminal activities than those who graduate in floating-market conditions. These effects are long-lasting and significant. Economic factors, therefore, play one of the crucial roles in determining crime rate levels, both when crime is observed aggregately and when it is disaggregated into separate components. Levitt (2001) notes that time-series analyses are too crude a tool for testing the connection between unemployment and crime and, consequently, the author gives priority to the panel sample analysis. CEE countries dealt with increased immigration during ' 90 s and '00s, which might be an underlying factor for the crime rate increase (Altindag, 2012). This paper will mention some of the most relevant studies that examined the relation between macroeconomic variables and crime rates in separate countries using time-series analysis, and focusing on their results and the trends of the relation. The sequence of operations in such studies consists of finding the order of integration of variable and then determining potential co-integration and causality. Numerous studies have shown that there is a long-term relation between macroeconomic variables and crime rates, and that there is causality 
which goes from macro variables towards crime (Luiz, 2001; Narayan and Smyth, 2004; Gillani et al., 2009; Teranda and Clement, 2014). On the other hand, recent literature in this field has also presented quite contrary conclusions of no long-term relation between the variables (Janko and Pople, 2015). The time-series analyses have used unemployment, poverty, and inflation as macroeconomic variables, as well as instruments of monetary and fiscal policy (Teles, 2004).

\section{DATA AND METHODOLOGY}

The primary objective of this paper is to examine a potential influence that unemployment may have on crime. The paper uses the unemployment rate and crime rate as variables of interest. The countries included in this study are: Czech Republic, Poland, Slovakia, Slovenia, Latvia, Lithuania, Bulgaria, Romania, Croatia, Hungary, and Estonia. The selected time period ranges from 1995 until 2015. The data are taken from WDI 2018 Database. As an indicator of unemployment, the data about the number of unemployed in the total labor force has been used (UN). As an indicator of criminal activities, we have used the intentional homicides $(C R)$ - registered number of homicides. The values of these indicators are presented as logarithms $(l n)$. Panel dataset is available publicly at Mendeley Data repository (https:// data.mendeley.com/datasets/7tptnz7ydz/1). For statistical analysis, we used STATA13 software package. The econometric model is specified as the following:

$$
\ln C R_{i t}=\theta_{i}+\delta_{i} t+\beta_{1}(\ln U N)_{i t}+\varepsilon_{i t}
$$

where $i=1,2, \ldots, \mathrm{N}$ is the index of the country, $t=1,2, \ldots, \mathrm{T}$ is the index of the temporal dimension, $\beta 1$ indicate the long-term effects of the independent on the dependent variable. $\theta i$ is country-specific fixed effects, while $\delta_{i} t$ is deterministic time trends specific for the country, while $\varepsilon_{i t}$ is error term. In our study, we have presented the period of 21 observations in 11 countries and the total number of observations is 231 . Table 1 shows the descriptive statistics for variables during the mentioned period of time:

Table 1 - Descriptive Statistics Results

\begin{tabular}{lcccccc}
\hline \multicolumn{1}{c}{ Country } & Mean $(\mathbf{C R})$ & Std. Dev $(\mathbf{C R})$ & JB $(\mathbf{C R})$ & Mean $(\mathbf{U N})$ & Std. Dev (UN) & J-B (UN) \\
\hline Czech Republic & 131.62 & 36.28 & 1.89 & 338169.1 & 77645.36 & 1.57 \\
\hline Poland & 690.71 & 432.77 & 18.49 & 2211310 & 712277.6 & 2.16 \\
\hline Slovakia & 100.81 & 29.09 & 1.34 & 377171.8 & 77574.99 & 1.41 \\
\hline Slovenia & 22.81 & 10.26 & 1.97 & 69791.76 & 15229.18 & 1.70 \\
\hline Latvia & 156.43 & 82.01 & 2.15 & 147750.2 & 48088.62 & 0.59 \\
\hline Lithuania & 297.33 & 87.72 & 0.35 & 199279.3 & 69142.57 & 1.16 \\
\hline Bulgaria & 243.28 & 117.59 & 2.17 & 423289.8 & 131451.9 & 0.48 \\
\hline Romania & 491 & 137.73 & 1.00 & 700883.3 & 98533.2 & 6.09 \\
\hline Croatia & 79.67 & 34.14 & 2.55 & 254953.8 & 48226.9 & 1.38 \\
\hline Hungary & 202.14 & 55.78 & 1.73 & 349128.9 & 83393.84 & 1.38 \\
\hline Estonia & 116.10 & 58.35 & 1.55 & 67575.14 & 20494.95 & 0.18 \\
\hline
\end{tabular}

Notes: Jarque and Bera (1980) 
Before applying specific unit root test, it is very important to specify cross-sectional dependencies. The Pesaran (2004) CD test for cross-equation correlation is used for testing cross-sectional dependence. The result of the cross-sectional independence test is reported in Table 2 . The probability value is under $5 \%$, so the effect is statistically significant. In this panel data model, disturbances are cross- sectionally dependent. In that sense, the second-generation panel unit root test should be used. These tests imply that there is a correlation between individual units of panel. Since the existence of the correlation between cross-sectional data has been already shown, this study applies the test developed by Pesaran (2007).

Table 2 - Pesaran (2004) CD Test Results

\begin{tabular}{llc}
\hline $\begin{array}{l}\mathrm{H}_{0:} \text { No cross-section dependence } \\
\text { (correlation) in residuals }\end{array}$ & Statistic & Probability \\
\hline Pesaran CD test & 23.64 & 0.000
\end{tabular}

In order to determine a long-term relationship between variables, the Westerlund (2007) test will be used. Based on the error correction model (ECM), this test implies 4 panel co-integration tests ( $\mathrm{Ga}$, $\mathrm{Gt}, \mathrm{Pa}$ and $\mathrm{Pt}$ ). These four test statistics are normally distributed, and based on structural dynamics, rather than residual dynamics. The Westerlund (2007) co-integration test is appropriate for small samples and it is possible to get reliable results. Moreover, this test has a power relative to other popular residual-based panel co-integration tests. The null hypothesis is tested by determining whether error correction is present for individual panel members and for the panel as a whole. If the null of no cointegration is rejected, then co-integration between the variables exists. Taking into account that all the variables are stationary after conversion into the first difference, co-integration test assumes the following data generating process:

$$
\Delta y_{i t}=\delta_{i}^{\prime} d_{t}+a_{i} y_{i(t-1)}+\pi_{i}^{\prime} x_{i(t-j)}+\sum_{j=1}^{m_{i}} a_{i j} \Delta y_{i(t-j)}+\sum_{j=0}^{m_{i}} \phi_{i j} \Delta x_{i(t-j)}+\omega_{i t}
$$

Where $d_{t}=(1-t)^{\prime}$ holds the deterministic components, $\delta_{i}^{\prime}$ represents the associated vector of parameters, while $\alpha_{i}$ is the speed adjustment term. If $\alpha_{i}<1$ then co-integration exists, while if $\alpha_{i}=1$, there is no co-integration. After testing co-integration, evaluation of the long-run parameters is carried out with the help of the panel Dynamic Ordinary Least Square (DOLS) developed by Pedroni (2001). This approach allows greater flexibility in the case of presence of heterogeneous co-integration vectors. Panel Dynamic OLS model can be represented as follows:

$$
y_{i t}=a_{i}+\beta x_{i t}+\sum_{j=-p_{i}}^{p_{i}} \phi_{i j} \Delta_{i t-j}+\varepsilon_{i t}
$$

where $\phi_{i j}$ represents the coefficients of the lead and lag differences, which accounts for possible serial correlation and endogeneity of the regressor(s), while $\pm p_{i}$ is the number of lags and leads. DOLS generates unbiased estimates for co-integrating variables, even with endogenous regressors, which is a very important feature of this procedure. 


\section{EMPIRICAL RESULTS}

Table 3 presents the results of the panel unit root test for the variables. Following the stationarity test, the null hypothesis cannot be rejected. PESCADF test starts from $\mathrm{H}_{0}$ : Variable is non stationary (has unit root). After conversion into the first difference, both variables became stationary. The null hypothesis is rejected at $1 \%$ level of significance.

Table 3 - Results of the Panel Unit Root Test

\begin{tabular}{lccc|ccc}
\hline \multicolumn{1}{l}{ Series } & \multicolumn{5}{c}{ PESCADF (constant \& trend) } \\
\hline & Level & \multicolumn{3}{c}{ First difference } \\
\hline $\ln (\mathrm{CR})_{\mathrm{it}}$ & -2.510 & -2.760 & -2.960 & -3.636 & -2.260 & -2.470 \\
\hline $\ln (\mathrm{UN})_{\mathrm{it}}$ & -2.534 & -2.760 & -2.960 & -3.287 & -2.260 & -2.470 \\
\hline
\end{tabular}

Notes: cv5 and cv1 are critical value at 5 and $1 \%$, respectively.

Therefore, we can conclude that the order of integration for both variables is I (1). In order to examine cointegration between the variables, the Westerlund (2007) test is used. Taking into consideration that the main focus of this paper is to examine the economic determinants of criminal activities, this paper presents only the case when $\ln (\mathrm{CR})$ it is a dependent variable. In Table 4, the null hypothesis about the non-existence of co-integration is rejected. In the specification when $\ln (\mathrm{CR})$ is considered as a dependent variable, 4 among 4 statistics of Westerlund (2007) were found to be statistically significant. In accordance with the aforementioned, it can be noted that variables are co-integrated.

Table 4 - Results of the Panel Co-integration Test

\begin{tabular}{|c|c|c|c|}
\hline \multicolumn{3}{|c|}{ Westerlund (2007) ECM co-integration test } & Null hypothesis: No co-integration \\
\hline Test statistics & Value & Z-value & Probability \\
\hline $\mathrm{Gt}$ & -3.714 & -5.500 & $0.00^{*}$ \\
\hline $\mathrm{Ga}$ & -15.284 & -1.596 & $0.05^{\star *}$ \\
\hline $\mathrm{Pt}$ & -11.654 & -5.314 & $0.00^{*}$ \\
\hline $\mathrm{Pa}$ & -15.027 & -3.296 & $0.00^{*}$ \\
\hline
\end{tabular}

Notes: ${ }^{*}$ and ${ }^{* *}$ refer to $1 \%$ and $5 \%$ of the test significance.

For the evaluation of the long-term effects of unemployment on crime rate, i.e., the long-term elasticity coefficient, the Dynamic Ordinary Least Square method was used. This study examines the case when lnCRit is a dependent variable. The findings reveal that there is a positive and statistically significant relation between the variables, which is in accordance with the hypothesis of this study (Table 5). Such a result is consistent with the theoretical views that higher unemployment rates, in some way, compel individuals to engage in illegal activities. The coefficient of elasticity in relation to unemployment and crime rate equals $0.6-0.63$. The interpretation of this result could be as the following: in the long run, an increase in the unemployment rate by $1 \%$ results in an increase in the crime rate of $0.6-0.63 \%$.

Table 5-DOLS Results

\begin{tabular}{llll}
\hline Variables & \multicolumn{2}{l}{ Dependent Variable: Crime } & \\
\hline & Pooled & Weighted & Grouped \\
\hline unemployment & $0.62(3.06)^{*}$ & $0.60(3.29)^{\star}$ & $0.63(2.76)^{\star}$ \\
\hline
\end{tabular}

Notes: *Denotes the significant at $1 \%$ levels. 


\section{CONCLUSION}

The goal of this study is to evaluate empirically the relationships between unemployment and the crime rate in the sample of 11 Eastern and Central European economies. Thus, it intends to fill the gap in the literature in this tradition. The aim of this research is important, because the countries chosen for this study share some characteristics, including changes in social structure and greater crime opportunities. This analysis does not differentiate between different categories of crime, but uses aggregated values of the variables. The appropriate test of dependence revealed that the unemployment rate has a positive impact on criminal activities, and that a $1 \%$ increase in the unemployment rate is related to a $0.6-0.63 \%$ increase in the crime rate. The key contribution of this paper is related to the fact that this is the first study that operates with the sample of CEE countries. Furthermore, this research can be a good starting point for future examining the relation between crime and unemployment in this part of Europe.

Policy implications of the results obtained in this manner refer to the fact that, in the selected countries, criminal activities can be decreased through a reduction of unemployment, i.e., through an improvement of the conditions on the labor market. Public policy against crime should include: more investment in human capital (education) and the reception of unemployment compensation. While the effect of unemployment benefits may be temporary, educational achievements should have permanent positive effects. In the context of future research, it was important to include additional variables in the analysis. First of all, appropriate indices of income inequality distribution must be included so that their impact and effect on crime can be examined.

\section{REFERENCES}

Almen, D. \& Nordin, M. (2011). Long term unemployment and violent crmes- using post-2000 data to reinvestigate the relationship between unemployment and crime. Lund University 34.

Altindag, D. (2012). Crime and unemployment: Evidence from Europe. International Review of Law and Economics, 32 (1), 145-157.

Baharom, A. \& Habibullah, M. (2008). Is crime cointegrated with income and unemployment?: A panel data analysis on selected European countries. Munich Personal RePEc Archive 11927.

Becker, G. (1968). Crime and Punishment: An Economic Approach. Journal of Political Economy, 76 (2), 169-218.

Bell, B. Bindler; A. \& Machin, S. (2014). Crime Scars: Recessions and the Making of Career Criminals. CEP Discussion Paper 1284.

Bindler, A. (2014). Still Unemployed, What Next? Crime and Unemployment Duration. University College London Job Market Paper

Cerro, A. \& Meloni, O. (2000). Determinants Of The Crime Rate In Argentina During The '90s. Estudios de Economia, 27(2), 297-311.

Cheong, T. S. \& Wu, Y. (2015). Crime rates and inequality: a study of crime in contemporary China. Journal of the Asia Pacific Economy, 20(2), 202-223. doi:10.1080/13547860.2014.964961.

Edmark, K. (2003). The Effects of Unemployment on Property Crime: Evidence from a Period of Unusually Large Swings in the Business Cycle. Working Papers 14.

Ehrlich, I. (1973). Participation in Illegitimate Activities: A Theoretical and Empirical Investigation. Journal of Political Economy, 81(3), 521-565. doi:10.1086/260058

Estrada, M. \& Ndoma, I. (2016). Assessing the impact of crime on the economic performance: the case of central America. Quality and Quantity, 50, 1201-1211. doi: 10.1007/s11135-015-0198-9

Gillani, S. Rehman, H. \& Gill, R. (2009). Unemployment, Poverty, Inflation and Crime Nexus: Cointegration and Causality Analysis of Pakistan. Pakistan Economic and Social Review, 47(1), 79-98.

Gould, E. Weinberg, B. \& Mustard, D. (2002). Crime rates and local labor market opportunities in the United States: 1979-1997. The Review of Economics and Statistics, 84(1): 45-61. doi:10.1162/003465302317331919 
Gruszczyńska, B. (2004). Crime in Central and Eastern European Countries in the Enlarged Europe. European Journal on Criminal Policy and Research, 10(2), 123-136. doi: 10.1007/s10610-004-3784-2

Im, K. Pesaran, H. \& Shin, Y. (2003). Testing for unit roots in heterogeneous panels. Journal of Econometrics, 115 (1), 53-74. doi:10.1016/s0304-4076(03)00092-7

Jarque, C., \& Bera, A. (1980). Efficient test for normality, heteroskedasticity and serial independence of regression residuals. Economic Letters, 6(3), 255-259.

Janko, Z. \& Popli, G. (2015). Examining the link between crima and unemployment: a time-series analysis for Canada. Applied Economics, 47(37), 4007-4019. doi:10.1080/00036846.2015.1023942

Justus, M. \& Kassouf, A. (2013). A cointegration analysis of crime, economic activity, and police performance in Sao Paulo city. Journal of Applied Statistics, 40(10), 2087-2109. doi:10.1080/02664763.2013.804905

Kim, S-W. \& Pridemore, W. (2005). Social support and homicide in transitional Russia. Journal of Criminal Justice, 33(6), 561-572. doi:10.1016/j.jcrimjus.2005.12.001

Lee, K. (2016). Unemployment and crime: the role of apprehension. European Journal of Law and Economics, doi:10.1007/s10657-016-9526-3

Levitt, S. (2001). Alternative Strategies for Identifying the Link Between Unemployment and Crime. Journal of Quantitative Criminology, 17(4), 377-390. doi:10.1023/a:1012541821386

Long, I. \& Polito, V. (2014). Unemployment, Crime and Social Insurance. Working Papers E2014/9. Cardiff Economics. doi:10.2139/ssrn.2483912.

Luiz, J. (2001). Temporal Association, the Dynamics of Crime, and their Economic Determinants: A Time Series Econometric Model of South Africa. Social Indicators Research, 53(1), 33-61. doi:10.1023/a:1007192511126

McCall, P. \& Brauer, J. (2014). Social welfare support and homicide: Longitudinal analyses of European countries from 1994 to 2010. Social Science Research, 48, 90-107. doi:10.1016/j.ssresearch.2014.05.009

Mocan, N. \& Unel, B. (2011). Skill-Biased Technological Change, Earnings of Unskilled Workers, and Crime. NBER Working Paper 17605, Cambridge. doi: 10.3386/w17605.

Mustard, D. (2010). How Do Labor Markets Affect Crime? New Evidence on an Old Puzzle. Discussion Paper Series IZA DP 4856

Narayan, P. \& Smyth, R. (2004). Crime rates, male youth unemployment and real income in Australia: evidence from Granger causality tests. Applied Economics, 36(18), 2079-2095. doi:10.1080/0003684042000261842

Papps, K. \& Winkelmann, R. (2000). Unemployment and Crime: New Answers to an Old Question. New Zealand Economic Papers, 34(1), 53-71. doi:10.1080/00779950009544315

Pedroni, P. (2001). Purchasing Power Parity Tests in Cointegrated Panels. The Review of Economics and Statistics, 83(4), 727-731. doi:10.1162/003465301753237803

Pesaran, H. (2007). A simple panet unit root in the presence of cross-section dependence. Journal of Applied Econometrics, 22(2), 265-312. doi:10.1002/jae.951

Pesaran, H. (2004). General diagnostic tests for cross section dependence in panels. Working Papers in Economics 0435, Cambridge.

Pridemore, W. Chamlin, M. \& Cochran, J. (2007). An interrupted time-series analysis of Durkheim's social deregulation thesis: The case of the Russian Federation. Justice Quarterly, 24(2), 271-290. doi:10.1080/07418820701294813

Pridemore, W. (2005). Social Structure and Homicide in Post-Soviet Russia. Social Science Research, 34(4), 732-756. doi:10.1016/j.ssresearch.2004.12.005

Rosenfeld, R. \& Messner, S. (2013). Crime and the Economy. SAGE Publications Ltd. doi:10.4135/9781446270097

Speziale, N. (2014). Does unemployment increase crime? Evidence from Italian provinces. Applied Economics Letters, 21(15), 1083-1089. doi:10.1080/13504851.2014.909568

Teles, V. (2004). The Effects of Monetary and Fiscal Policies on Crime. Economics Bulletin, 11(1), 1-9.

Westerlund, J. 2007. 'Testing for Error Correction in Panel Data'. Oxford Bulletin of Economics and Statistics 69(6): 709-748, doi:10.1111/j.1468-0084.2007.00477.x

World Bank (2016). World Development Indicators. D.C. The World Bank Group.

\section{ACKNOWLEDGEMENTS:}

This work was supported by the Ministry of Science, Education and Technological Development of Serbia under Grant [179015] 
DA LI STOPA NEZAPOSLENOSTI DOVODI DO KRIMINALNIH RADNJI? EMPIRISJKA ANALIZA EKONOMIJA CENTRALNE I ISTOČNE EVROPE (CEE)

\section{Rezime:}

Ovaj rad pokušava osvetliti odnos između kriminogenog ponašanja i nezaposlenosti, sa posebnim osvrtom na zemlje u centralnom i istočnom delu Evrope. Rad se oslanja na pretpostavku da je ekonometrijsko modeliranje odnosa između ovih promenljivih veoma važno za objašnjenje ekonomskog i društvenog rasta. Naš rezultat je u skladu sa pretpostavkom da se zločin povećava kada raste nezaposlenost. Ovi rezultati sugerišu da se, u cilju borbe protiv kriminala, analiziraju sve strategije za ublažavanje nezaposlenosti. Nadalje, radi uspešnog smanjenja stope kriminala, vlade u zemljama centralne i istočne Evrope treba da rade na postizanju makroekonomske stabilnosti.

Ključne reči:

stopa nezaposlenosti, kriminal, ekonometrija panel podataka, istočna i centralna Evropa. 